\title{
LANSKAP PERKEBUNAN TEMBAKAU KEBONARUM DAN GAYAMPRIT KABUPATEN KLATEN
}

\section{LANDSCAPE OF TOBACCO PLANTATIONS AT KEBONARUM AND GAYAMPRIT, KLATEN REGENCY}

\author{
Galih Sekar Jati Nagari \\ Mahasiswa S2 IImu Arkeologi, Fakultas IImu Budaya \\ Universitas Gadjah Mada \\ galih.nagari@gmail.com
}

\begin{abstract}
Klaten is a region in Surakarta residency in 18-20th century during Colonial era. It held an important role in the economy of Surakarta region during that period. Klaten became area with the highest plantation productivity in Surakarta. Several plantation companies were established in Klaten, including sugar industries, indigo plantations, and tobacco plantations. Today, several plantation infrastructures can be observed, and its historical background can be traced well, but researches about Klaten Colonial industries are seldom. There are operating tobacco plantations in Klaten Regency, located in Kebonarum and Gayamprit. Plantation area in Kebonarum and Gayamprit is used as research material. Survey and historical approach are used in this research. This project aims to explore the important role of Colonial plantations in rural societies, through archaeological environment phenomenon and its history. The existence of plantations in Klaten rural areas was able to offer social change to the societies in Colonial era.
\end{abstract}

Keywords: Landscape, Plantation, Tobacco, Colonial, Klaten.

\begin{abstract}
ABSTRAK
Klaten merupakan sebuah kabupaten di bawah Karesidenan Surakarta pada Abad XVIIIXX Masehi. Ia memegang peran penting dalam perekonomian di wilayah Surakarta pada masa Kolonial, dikarenakan menjadi salah satu daerah dengan hasil perkebunan yang besar pada masa tersebut. Beberapa perusahaan perkebunan pernah didirikan di Klaten, antara lain industri gula, perkebunan indigo, dan perkebunan tembakau. Hingga kini masih terdapat sarana-prasarana perkebunan dan masih dapat ditelusuri dengan baik sejarahnya, namun jarang diteliti. Salah satu area perkebunan di Klaten terdapat di wilayah Kebonarum dan Gayamprit, yang saat ini merupakan wilayah setingkat kecamatan dan desa. Perkebunan di area Kebonarum dan Gayamprit hingga kini masih beroperasi dan dijadikan bahan penelitian. Penelitian ini dilakukan di kedua wilayah tersebut melalui survey dan kajian sejarah. Gambaran lingkungan dan sejarahnya digunakan untuk menelusuri peran penting perkebunan terhadap masyarakat pedesaan pada masa lalu. Adanya perkebunan di wilayah pedesaan mampu memberikan perubahan sosial terhadap masyarakatnya.
\end{abstract}

Kata kunci: Lanskap, Perkebunan, Tembakau, Kolonial, Klaten.

\author{
Tanggal Masuk : 04 April 2018 \\ Tanggal Diterima : 07 Januari 2019
}




\section{PENDAHULUAN}

Tembakau merupakan salah satu komoditas perkebunan yang cukup banyak dihasilkan di wilayah Nusantara, selain tanaman teh, tebu, kelapa sawit, dan lain-lain. Penanaman tembakau diketahui telah ada sejak abad XVII dan berlanjut sebagai bagian dari sistem tanam (cultuurstelsel) pada pertengahan abad XIX, bersamaan dengan komoditas lain yaitu tebu, teh, dan kopi. Pada awalnya, tembakau banyak ditanam di beberapa daerah seperti Kedu, Situbondo, Kediri, Semarang, dan Surabaya. Hingga pada masa setelahnya banyak ditanam di wilayah Vorstenlanden, termasuk salah satunya di Klaten (Dell dan Olken, 2017: 7-8; Djajadi, 2015: 27). Vorstenlanden secara harfiah berarti "negara kerajaan" dalam Bahasa Belanda, istilah ini digunakan Pemerintah Hindia-Belanda untuk menyebut wilayah Kasunanan Surakarta dan Kasultanan Yogyakarta.

Wilayah Klaten sangat potensial untuk digunakan sebagai daerah perkebunan. Ini dikarenakan sebagian besar wilayahnya merupakan lahan yang subur dengan debit air yang baik, disertai dengan iklim yang cocok untuk beberapa tanaman perkebunan.

Sejak masa pemerintahan Hindia-Belanda hingga kini, beberapa wilayah di Klaten masih digunakan sebagai perkebunan. Beberapa jenis tanaman yang hingga kini ditanam oleh masyarakat antara lain tanaman tebu dan tembakau. Tanaman-tanaman tersebut ditanam di lahan milik penduduk dengan fasilitas pendukung pengolah perkebunan yakni pabrik gula dan pabrik pengolahan tembakau milik pemerintah. Beberapa pabrik pengolahan tembakau tersebut terdiri dari Pabrik Pengolahan Tembakau di

Wedi Birit, Gayamprit, dan Kebonarum.

Beberapa tulisan telah banyak membahas mengenai industri gula di Klaten, namun belum banyak membahas industri tembakaunya. Tulisan ini merupakan awal penelitian mengenai industri tembakau di Klaten, mengingat akses untuk penelitian yang lebih mendalam terhadap industri perkebunan milik pemerintah masih sulit. Selain itu, tulisan ini akan mengambil kasus pada wilayah Gayamprit dan Kebonarum, karena kedua wilayah tersebut merupakan wilayah Onderneming atau perkebunan yang bersebelahan satu dengan lain, yakni Onderneming Kebonarum dan Onderneming Gayamprit. Hubungannya dapat terlihat jelas, karena masih terdapat dalam satu ruang lingkup kawasan. Kedua wilayah tersebut terdapat dalam satu kawasan onderdistrik atau setingkat kecamatan, yakni Onderdistrik Kebonarum, Distrik atau Kawedanan Kota Klaten pada awal 1930-an (Tim Penyusun Hari Jadi Kab. Klaten, 2005: 95-96; Topografische Dienst Batavia, 1933-1935).

Oleh sebab itu, penelitian ini diharapkan dapat memaparkan seperti apa kondisi perkebunan Kebonarum-Gayamprit yang kini masih menjadi perkebunan aktif di Kabupaten Klaten sejak masa Pemerintahan Hindia-Belanda hingga masa sekarang, dan bagaimana hubungan perkebunan tersebut dengan masyarakat pada masa lampau.

\section{METODE PENELITIAN}

Penelitian ini merupakan eksplorasi dengan observasi secara langsung di kawasan KebonarumGayamprit. Hasil yang diperoleh dari 
observasi di lapangan berupa dokumentasi foto dan catatan deskripsi kondisi fasilitas-fasilitas perkebunan, dan lingkungan perkebunan. Selain menggunakan observasi langsung, penulis juga menggunakan kajian pustaka, mengingat beberapa ahli sejarah telah menulis tentang sejarah perekonomian perkebunan di wilayah Surakarta. Penulis menggunakan pendekatan lanskap dan historis dalam menganalisis hubungan antara wilayah perkebunan dengan masyarakat desa. Pendekatan lanskap digunakan untuk memahami berbagai hubungan makna karya dengan masyarakat pendukungnya (Anschuetz, dkk., 2001: 164). Dalam hal ini, penulis berusaha melihat seperti apa lingkungan perkebunan Kebonarum-Gayamprit yang dibentuk oleh masyarakat di masa Kolonial. Penelusuran sejarah dilakukan untuk mengetahui berbagai latar belakang sosial-ekonomi pada masa Kolonial, yang diperoleh dari kajian pustaka. Gambaran lingkungan perkebunan kemudian dihubungkan dengan sejarah dan kondisi sosial di wilayah perkebunan yang terjadi di masa tersebut.

\section{HASIL PENELITIAN}

\section{Perkebunan Tembakau Di Klaten}

Wilayah perkebunan di Klaten digunakan sebagai wilayah perkebunan dimulai sejak pembukaan politik pintu terbuka (liberalisme) dengan diberlakukannya UU Agraria 1870. Akibatnya, undang-undang tersebut, banyak pihak asing, sebagian besar berasal dari Eropa, mendirikan investasi di Hindia-Belanda. Wilayah Vorstenlanden yang sebelumnya tidak terkena dampak dari sistem tanam, akhirnya juga dijadikan tempat investasi para pengusaha Eropa untuk mendirikan perusahaan perkebunan (Padmo, 2007: 4). Sejak pertengahan abad XIX, mulai banyak perusahaan perkebunan Belanda melakukan uji coba penanaman tembakau di kawasan Vorstenlanden. Namun, sebagian besar industri tembakau dikelola oleh NV. Klattensche Cultuur Maatschappij (KCM) pada akhir masa pemerintahan Hindia-Belanda (Padmo, 1999: 26).

Dari sekian banyak tanaman komoditas pada perkebunan di wilayah Vorstenlanden, tanaman tebu dan tembakau memegang peran paling penting dalam perekonomian, sehingga paling banyak ditanam. Klaten merupakan salah satu wilayah dengan jumlah perkebunan terbanyak, serta merupakan daerah penghasil gula dan tembakau yang paling produktif dibandingkan dengan wilayah lain di Surakarta. Hal ini kemungkinan dikarenakan oleh kondisi wilayah Klaten yang subur karena endapan volkanik Gunung Merapi, dengan debit air yang baik, dan iklim yang sesuai (Dirjen Cipta Karya PU dalam Nagari, 2013: 18).

Berikut merupakan daftar produksi gula dan tembakau di wilayah Kasunanan Surakarta dan Mangkunegaran, serta komoditas lain dan jumlah perkebunan swasta asing di Kasunanan Surakarta: 
Tabel 1. Daftar Produksi Gula dan Tembakau di Kasunanan Surakarta dan Mangkunegaran

\begin{tabular}{|c|c|c|c|c|c|c|}
\hline Tahun & Surakarta & Boyolali & Klaten & Sragen & Wonogiri & Mangkunegaran \\
\hline \multicolumn{7}{|c|}{ Gula (dalam ribuan pikul) } \\
\hline 1890 & - & 103 & 203 & 26 & - & 48 \\
\hline 1900 & 66 & 41 & 520 & 98 & - & 102 \\
\hline 1910 & 91 & 112 & 829 & 183 & - & 195 \\
\hline \multicolumn{7}{|c|}{ Tembakau (dalam ton) } \\
\hline 1890 & 11 & 35 & 950 & 54 & 3 & - \\
\hline 1900 & 614 & 295 & 4454 & 306 & 49 & - \\
\hline 1910 & 839 & 200 & 5255 & 121 & 6 & - \\
\hline
\end{tabular}

Sumber: Shiraishi, dalam PPEB UNS, 2007: 54

Tabel 2. Daftar Jumlah dan Komoditas Perkebunan di Wilayah Surakarta masa kolonial

\begin{tabular}{llcc}
\hline No. & Kabupaten & $\begin{array}{c}\text { Jumlah } \\
\text { Perkebunan }\end{array}$ & Jenis Tanaman \\
\hline 1. & Surakarta & 10 & Tembakau, indigo, gula, kopi, agave \\
2. & Klaten & 35 & Tembakau, indigo, gula, agave \\
3. & Boyolali & 18 & Tembakau, kopi, indigo, lada, karet, kapas \\
4. & Sragen & 35 & Kopi, indigo, karet, teh, gula, agave, kapas \\
5. & Jumlah & 98 & \\
\hline
\end{tabular}

Sumber: PPEB UNS, 2007: 55

Perkebunan tembakau di Klaten, memiliki sistem yang sama dengan perkebunan lainnya. Perusahaan perkebunan menggunakan sistem sewa tanah dalam jangka waktu lama untuk ditanami tanaman tembakau. Tanah disewakan dari tanah milik Kasunanan Surakarta, pada perkembangannya menjadi milik perorangan dan desa. Tanah-tanah tersebut awalnya merupakan tanah apanage atau tanah lungguh yang kemudian diubah sistem pengelolaannya oleh Kasunanan Surakarta untuk disewakan kepada para pengusaha asing (Suhartono, 1991: 27-29; 97-98). Menurut Sugijanto Padmo, penanaman tembakau di Klaten dimulai di sekitar daerah Gondang pada 1858 oleh Mendez da Costa, baru kemudian berkembang ke daerah-daerah lainnya seperti Kebonarum, Wedi Birit, dan Delanggu (Sujatmiko, 2014: 4-5).

Tidak seluruh tanah digunakan untuk tanaman tembakau, terdapat perselingan penanaman pada setiap tahunnya, kemungkinan besar diselingi dengan tanaman padi, sama seperti saat ini. Tanaman tembakau dapat tumbuh baik ketika berada dalam iklim kering dibawah sinar matahari langsung, sehingga baik ditanam pada masa kemarau sekitar bulan Juli-September.

Total masa tanam tanaman tembakau sekitar lima bulan, dari 
pembenihan hingga panen. Awalnya membutuhkan media benih, baru kemudian dapat ditanam pada tanah perkebunan secara langsung (Zadoks ed., 2014: 12-14). Setelah panen, tembakau dikumpulkan untuk dikeringkan, proses pengeringan ini dapat dilakukan dengan dijemur dibawah sinar matahari langsung, namun untuk Tembakau Vorstenlanden yang ditanam di area ini, pengeringan dilakukan di malam hari dengan perapian di bangunan vernakular khusus, yang biasa disebut los. Setelah kering, daun tembakau baru dibawa ke pabrik pengolahan tembakau untuk disortir, dirapikan, dan dikemas.

Produksi tembakau di Klaten sangat baik, ini terlihat dengan adanya laboratorium penelitian tembakau yang terdapat di Kota Klaten. Proefstation voor Vorstenlandsche Tabaks atau laboratorium penelitian tembakau ini didirikan pada 1898 dan hingga kini masih beroperasi dibawah PTPN X. Pada awalnya laboratorium tersebut didirikan oleh tiga perusahaan swasta, namun pada 1905 diambil alih oleh Departemen Pertanian Hindia-Belanda. Pada 1910, laboratorium berdiri sendiri dalam Algemeen Proefstation, berpusat di

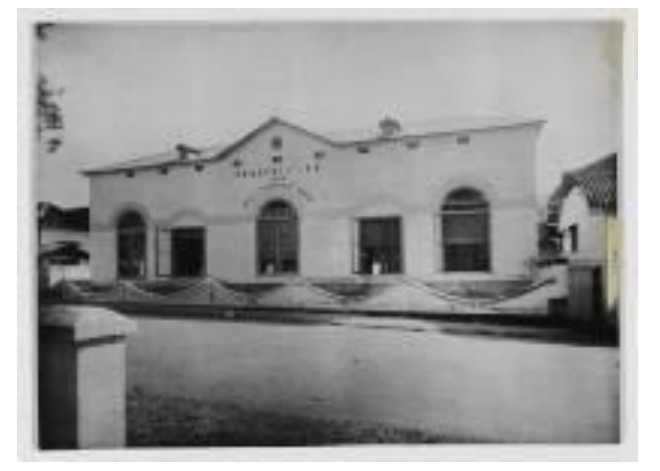

Gambar 1. Proefstation voor

Vorstenlandsche Tabaks Klaten 1910 (Sumber: Media-kitlv.nl)

Salatiga. Pada 1939, laboratorium di Klaten keluar dari gabungan tersebut dan berdiri sendiri, hingga pada 1957

diambil alih oleh Pemerintah Republik Indonesia (Pusat Penelitian Tembakau PTPN X (Persero) Klaten 2012).

Dari sumber KITLV, pada masa Pemerintahan Hindia-Belanda, perkebunan tembakau tidak hanya terdapat di Wedi Birit, Gayamprit, dan Kebonarum, melainkan juga terdapat di Jogonalan, Puluhwatu, Polanharjo, Delanggu, dan beberapa daerah lainnya (media-kitlv.nl, 02 Juni 2017). Namun, hingga kini, pabrik pengolahan yang masih beroperasi hanya pabrik di Wedi Birit, Gayamprit, dan Kebonarum. Dari sekian banyak area perkebunan, area Wedi Birit, Kebonarum, Gayamprit, dan Polanharjo memiliki ongkos produksi dan harga tembakau tertinggi, dengan daerah penghasil terluas, sejak 1916 hingga 1932 (Padmo, 1999: 173-174; 178). Pabrik Pengolahan Tembakau Kebonarum dan Gayamprit pada awalnya diketahui merupakan milik NV. KCM, bersama dengan pabrikpabrik lainnya selain tembakau termasuk Pabrik Gula Gondang Winangun. Tembakau yang saat ini ditanam di ketiga perkebunan tersebut merupakan Tembakau Vorstenlanden, yang digunakan untuk cerutu dan diekspor ke luar negeri.

\section{Kondisi Lanskap Wilayah Perkebunan Tembakau Kebonarum-Gayamprit}

Gayamprit dan Kebonarum merupakan dua wilayah administrasi di tingkat kelurahan dan kecamatan. Kelurahan Gayamprit merupakan bagian dari Kecamatan Klaten Selatan, sedangkan Kebonarum merupakan sebuah wilayah kecamatan. Di kedua wilayah ini terdapat dua pabrik pengolahan 
tembakau, yang saat ini berada di diketahui komponen-komponen bawah kepemilikan PTPN X. Jarak

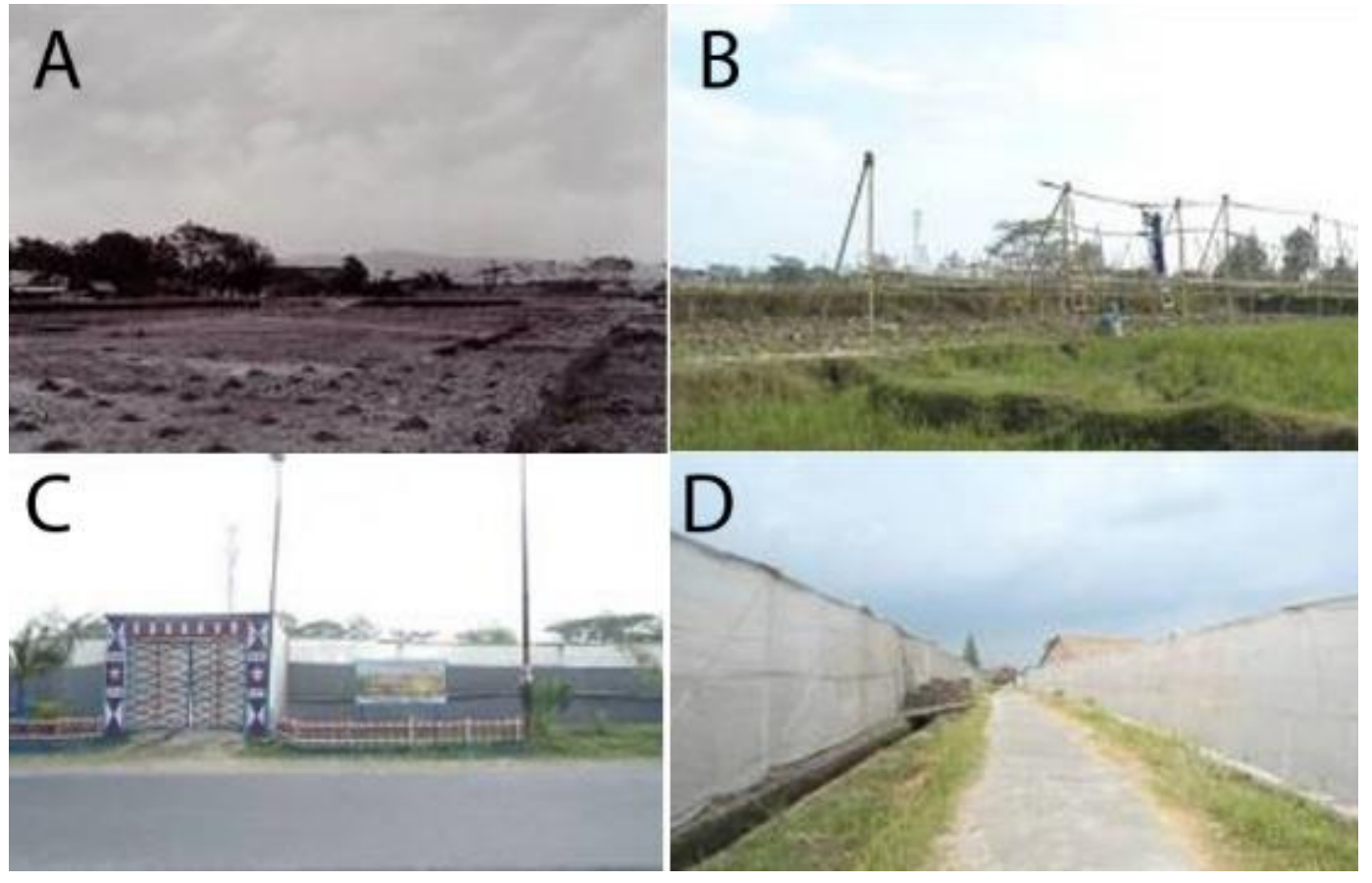

Gambar 2. (A) Kondisi Lahan di Kebonarum Sebelum Tanam Tembakau 1915, (Sumber: mediakit/v.nl), (B) Kegiatan Pemasangan Kerangka Penutup Tembakau, (C) Tempat Pembibitan Tembakau di Kebonarum, (D) Daerah Persawahan yang Digunakan untuk Penanaman Tembakau (Sumber: Dokumentasi Penulis 2017)

dari Pabrik Pengolahan Tembakau Gayamprit ke Pabrik Pengolahan Tembakau Kebonarum cukup dekat, yaitu kurang dari tiga kilometer. Di sekitar wilayah tersebut merupakan wilayah pertanian dengan daerah persawahan yang luas, serta permukiman.

Wilayah perkebunan tembakau Gayamprit dan Kebonarum dilengkapi dengan beberapa fasilitas perkebunan. Fasilitas-fasilitas tersebut menunjang kegiatan perkebunan yang dikelola oleh pengusaha asing Eropa. Oleh karena itu, terdapat beberapa fasilitas yang bersifat modern sehubungan dengan tuntutan hidup beberapa penduduk Eropa yang tinggal di sekitar wilayah perkebunan tersebut.

Dilihat dari sumber peta dan pengamatan di lapangan, dapat

\section{Lahan Perkebunan}

Ketersediaan lahan yang baik merupakan persyaratan utama dari usaha perkebunan. Dalam sistem perkebunan tembakau ketersediaan lahan juga berhubungan dengan masa tanam. Lahan di sekitar Gayamprit dan Kebonarum merupakan lahan persawahan milik desa, perorangan, dan Kasunanan Surakarta.

Lahan baru akan ditanami tanaman tembakau ketika akan datang masa tanam yakni sekitar bulan Juli-September, atau di musim kemarau. Oleh karena itu ketika musim tanam belum tiba, maka lahan biasanya ditanami tanaman pangan, terutama padi.

Lahan yang digunakan untuk menanam tanaman tembakau harus diolah terlebih dahulu. Sebelum 
ditanami, tanah harus dipupuk, kemudian dibentuk pematangpematang yang memanjang, dengan aliran-aliran irigasi kecil.

Pada saat ini, musim tanam tembakau ditandai dengan ditutupnya lahan-lahan yang disewa tersebut dengan kain kasa yang disangga dengan bambu. Sehingga tidak terlihat jelas dari luar. Hal ini dimaksudkan untuk menaungi tembakau tersebut, karena jenisnya merupakan tembakau dalam naungan.

\section{Bangunan Los}

Bangunan ini merupakan bangunan non-permanen, berbentuk empat persegi panjang. Bangunan los merupakan bangunan yang luas, rata-rata memiliki panjang $100 \mathrm{~m}$ dengan lebar $18 \mathrm{~m}$, dan tinggi $12 \mathrm{~m}$.
Karena rentan ambruk, biasanya memanjang ke arah utara-selatan, untuk menghindari angin dari utaraselatan (Saraswati, 2008: 67-72).

Los digunakan sebagai tempat transit tanaman tembakau, baik dari bibit sebelum ia ditanam di lahan, dan tempat pengeringan tembakau setelah di panen. Tembakau akan dikeringkan dengan cara diasapi pada malam hari menggunakan perapian dari sekam padi. Hingga daun cukup kering, untuk kemudian siap dibawa ke pabrik pengolahan.

Terdapat cukup banyak los di sekitar wilayah perkebunan Gayamprit dan Kebonarum. Biasanya los terdapat pada tanah kas desa yang disewakan. Beberapa tanah sudah tidak diperpanjang masa sewanya, sehingga jumlah los saat
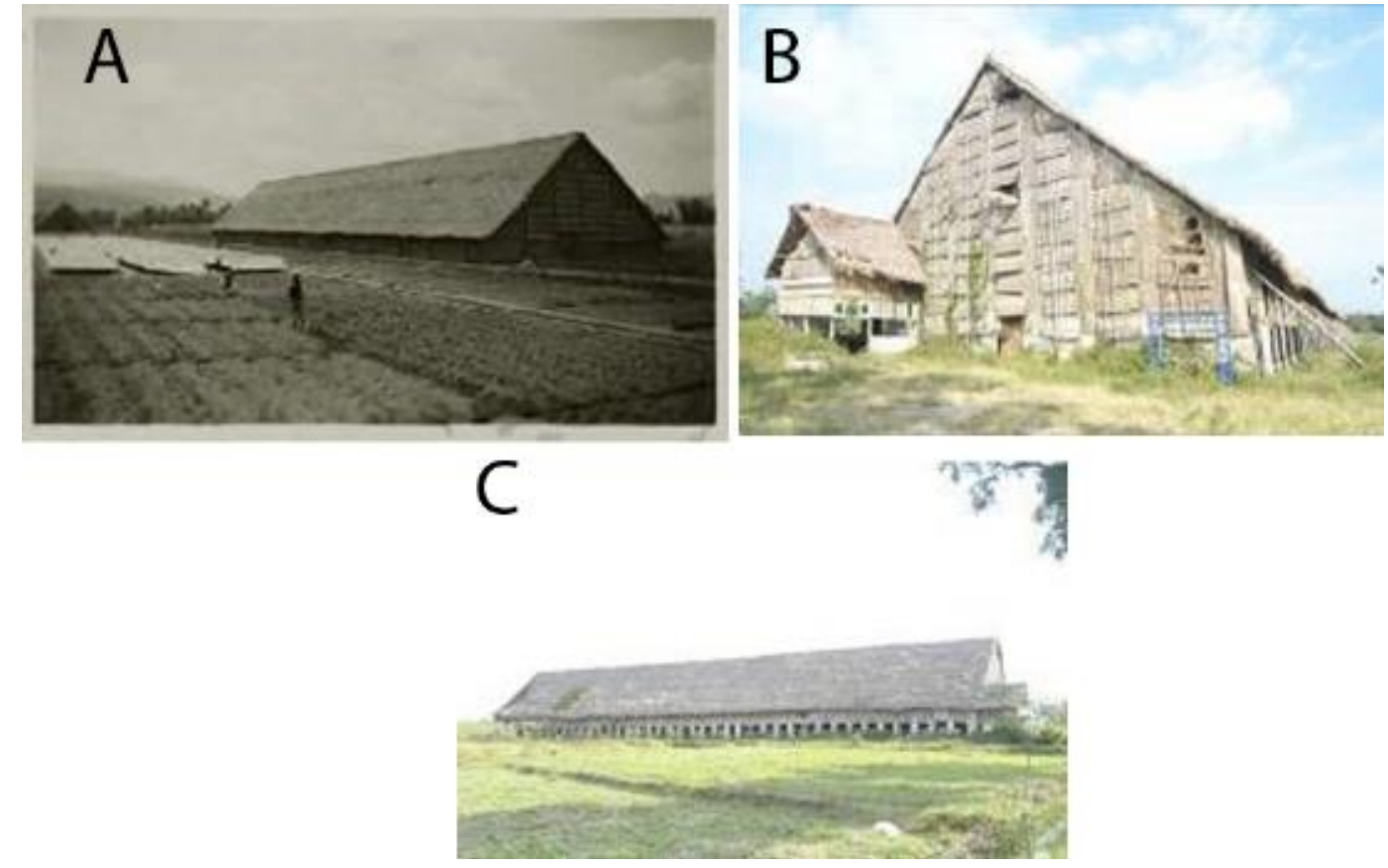

Gambar 3. (A) Kondisi Tempat Pembibitan dan Bangunan Los di Kebonarum 1931, Sumber: media-kitlv.nl, (B) Bangunan Los Tampak Depan, (C) Bangunan Los Tampak Samping

(Sumber: Dokumentasi Penulis 2017)

Terbuat dari bahan bambu sebagai tiang-tiang penyangga, beratap pelana dengan bahan daun tebu kering, bahan anyaman bambu digunakan sebagai penutup dinding. ini semakin berkurang.

\section{Pabrik Pengolahan Tembakau}


Komponen penting lain yang terdapat dalam wilayah perkebunan tembakau yaitu pabrik pengolahan tembakau. Pabrik pengolahan tembakau di Gayamprit dan Kebonarum masing-masing merupakan kompleks bangunan yang luas, dan terdiri dari beberapa permukiman sebagai rumah tinggal para pegawai, dan gudang.

Pabrik Pengolahan Tembakau Kebonarum secara administratif terletak di Jalan Kebonarum-Gayamprit, Desa Basin, Kecamatan Kebonarum. Secara astronomis terletak pada $7^{\circ} 42^{\prime} 04,52$ "
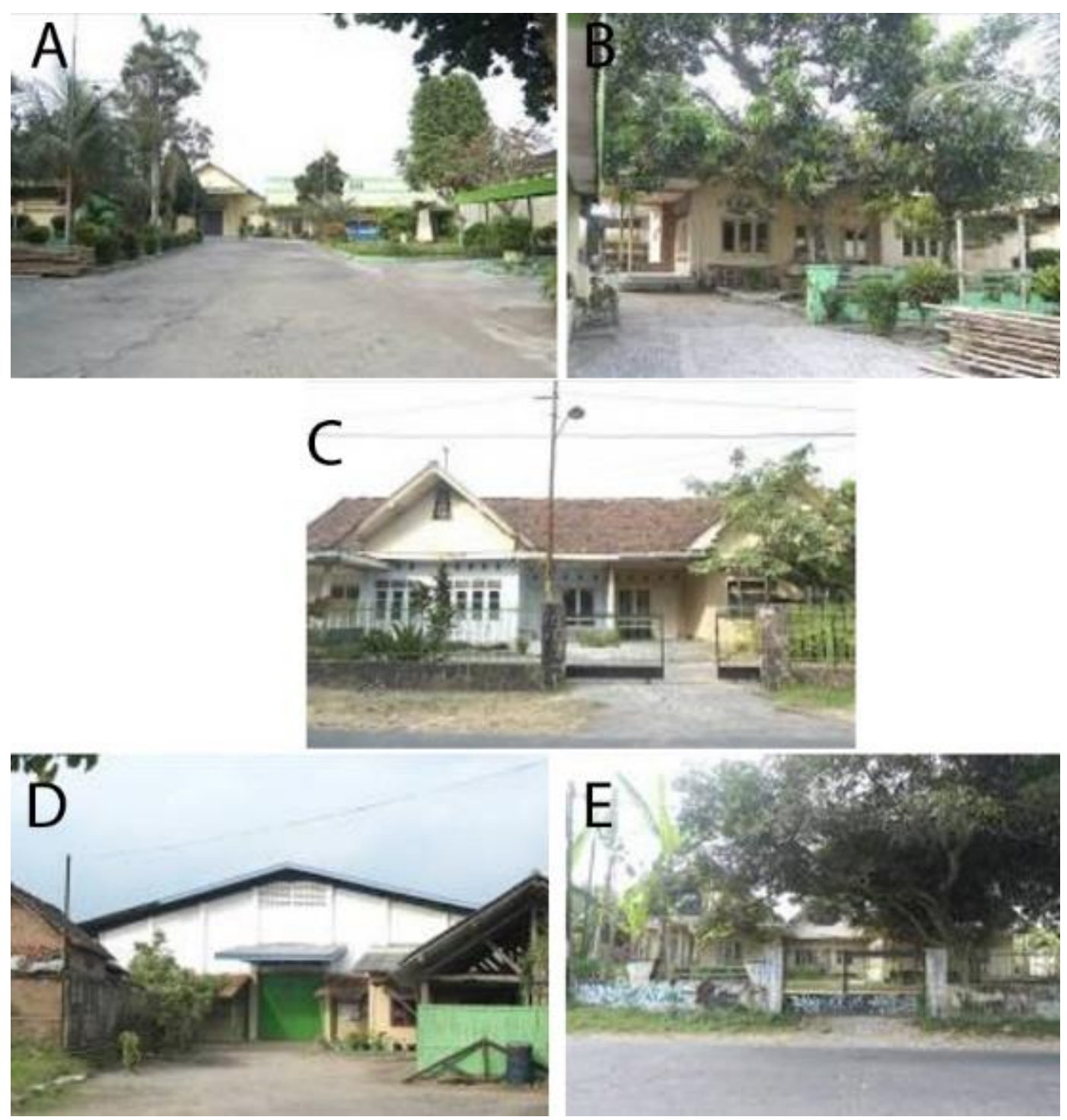

Gambar 4. (A) Bangunan Pabrik Pengolahan Tembakau Kebonarum, (B) Bangunan Perkantoran, (C) Bangunan Rumah Dinas Pegawai, (D) Bangunan Gudang Magazen, (E) Bangunan Rumah Dinas Pegawai di Selatan Gudang Magazen.

(Sumber: Dokumentasi Penulis 2017)

komponen. Selain bangunan pabrik, di sekitarnya juga terdapat bangunan perkantoran, bangunan-bangunan
LS dan 110 ${ }^{\circ} 33^{\prime} 43,56^{\prime \prime}$ BT. Pabrik Pengolahan Tembakau Kebonarum memiliki beberapa komponen, yaitu 
bangunan pabrik, gudang, beberapa bangunan perkantoran, dan beberapa bangunan rumah dinas pegawai. Bangunan-bangunan perkantoran dan rumah dinas pegawai terdapat di utara bangunan pabrik. Selain itu juga terdapat gudang di sebelah utara, dan gudang magazen serta rumah dinas pegawai di sebelah timur pabrik, terletak agak jauh dipisahkan oleh permukiman penduduk. Keseluruhan kompleks bangunan merupakan bangunan yang memiliki perpaduan modern Eropa dengan aspek lokal, atau yang disebut dengan Gaya Indis. Hingga kini, seluruh kompleks bangunan baik bangunan pabrik, kantor, dan rumah dinas masih digunakan untuk kepentingan perkebunan milik PTPN $X$ Unit Kebonarum, Gayamprit, dan Wedi Birit.

Pabrik Pengolahan Tembakau Gayamprit terletak di Jalan Wilis, secara administratif terdapat di Kelurahan Gayamprit, Kecamatan Klaten Selatan. Secara astronomis terletak pada $7^{\circ} 42^{\prime} 06,10^{\prime \prime}$ LS dan $110^{\circ} 35^{\prime} 15,84$ " BT. Sama seperti Pabrik Pengolahan Tembakau
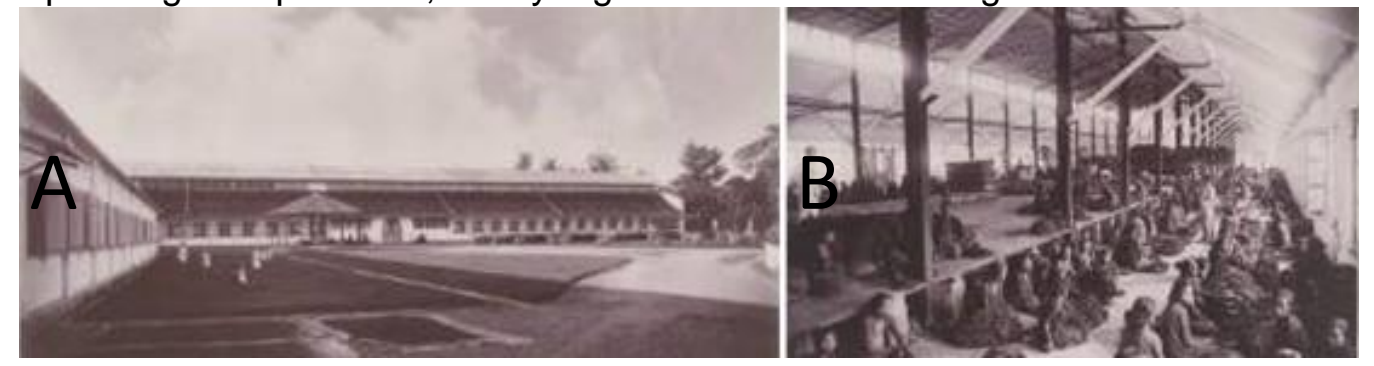

Gambar 5. (A) Pabrik Pengolahan Tembakau Gayamprit 1925, (B) Kegiatan Pemilihan Tembakau di Pabrik Pengolahan Tembakau Gayamprit 1925

(Sumber: media-kitlv.nl)
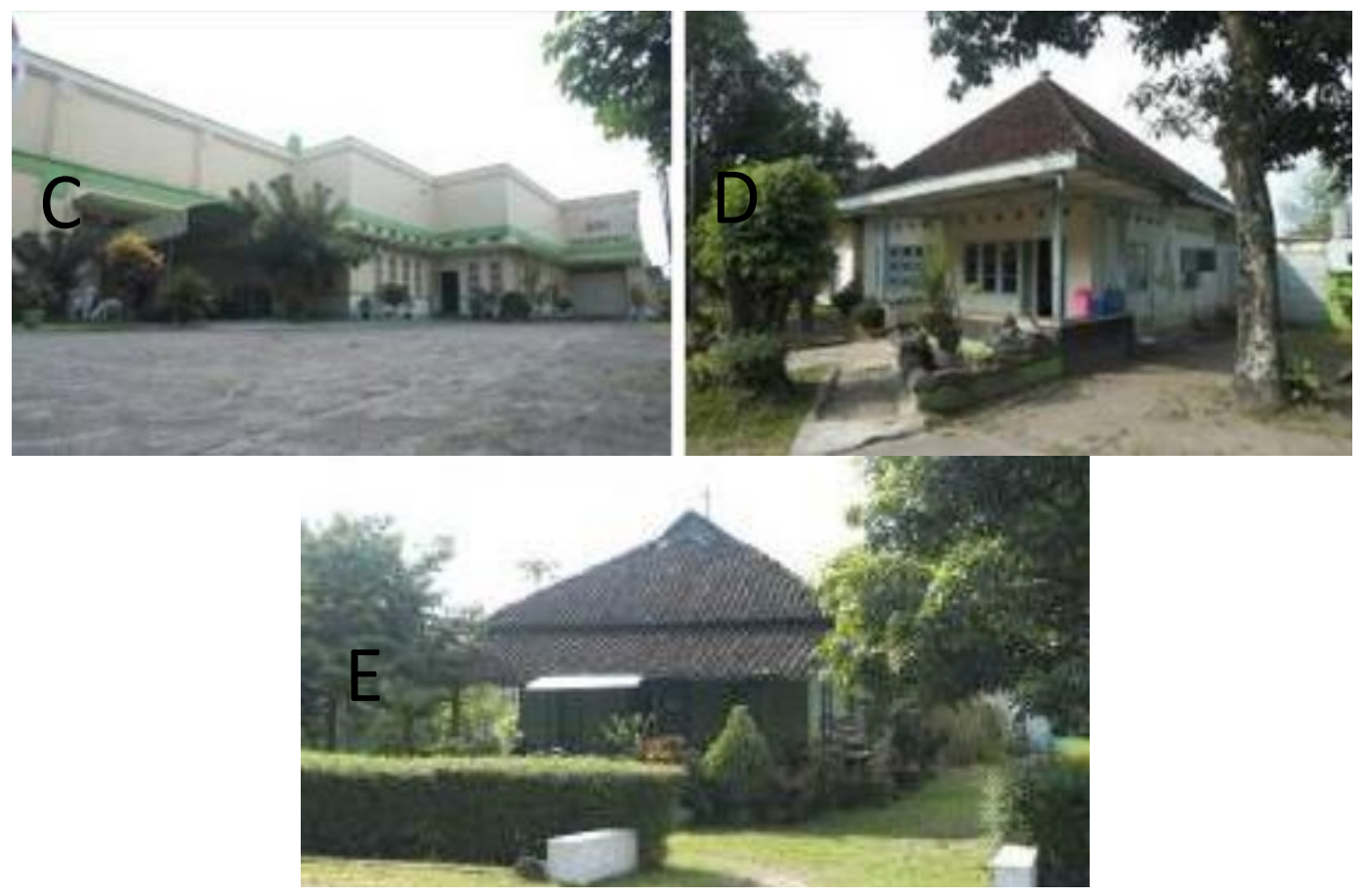

Gambar 6. (C) Pabrik Pengolahan Tembakau Gatamprit Tampak Depan, (D) Bangunan Kantor di dalam Kompleks Pabrik, (E) Bekas Bangunan Rumah Dinas Pegawai Pabrik,

(Sumber: Dokumentasi Penulis 2017) 
Kebonarum, pabrik ini juga dilengkapi beberapa komponen lain, seperti bangunan pabrik, gudang, bangunan kantor, dan bangunan rumah dinas pegawai. Bentuk bangunan masih serupa dengan bangunan kompleks pabrik di Kebonarum yang memiliki Gaya Indis. Kompleks bangunan pabrik, kantor, dan gudang terdapat dalam satu kompleks, sedangkan bangunan-bangunan rumah dinas terpisah di sisi selatan kompleks pabrik. Saat ini kompleks pabrik beserta gudang dan kantor dimiliki oleh PTPN $X$, namun bangunanbangunan rumah dinas pegawai dikelola oleh Kodim 0723/ Klaten sebagai asrama anggota TNI.

\section{Rumah Sakit}

Berdasarkan peta 1933 dan 1935, serta keterangan dari penduduk, terdapat rumah sakit di wilayah Perkebunan Gayamprit dan Kebonarum. Rumah sakit ini kemungkinan merupakan rumah sakit perkebunan. Tepatnya terletak sekitar $1 \mathrm{~km}$ di barat Pabrik Pengolahan Tembakau Kebonarum, dan sekitar 1,5 km di timur Pabrik Pengolahan Tembakau Gayamprit.

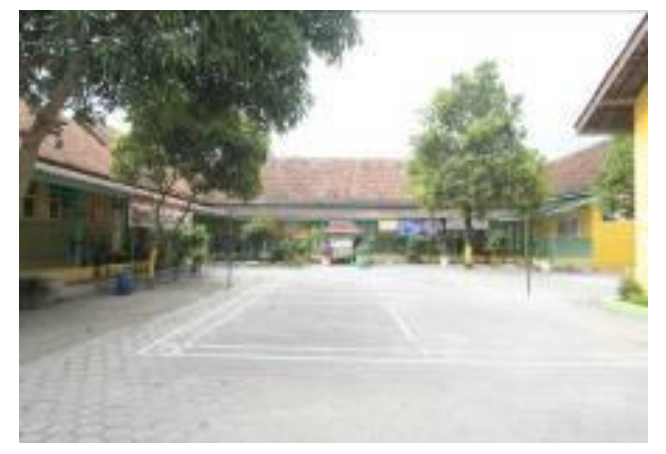

Gambar 7. Bekas Bangunan Rumah Sakit (Sumber: Dokumentasi Penulis 2017)

Saat ini bangunan rumah sakit telah berubah fungsi menjadi bangunan SD Negeri 1 Nglinggi. Bangunan yang lama masih dapat terlihat, meskipun sudah terdapat banyak penambahan bangunan baru. Bangunan yang lama memanjang timur-barat, memiliki beberapa buah pintu dan jendela kayu.

\section{Pengairan \\ Wilayah Gayamprit dan} Kebonarum termasuk dalam patahan timur-selatan Gunung Merapi. Daerah patahan tersebut banyak ditemukan mata air, atau dikenal dengan sebutan umbul. Mata air dengan debit air terbesar terdapat di Desa Geneng. Mata air tersebut digunakan untuk sumber air di Kota Klaten dan wilayah di sekitar Kebonarum-Gayamprit. Instalasi di Geneng telah dibuat sejak masa Hindia-Belanda, dengan saluran berupa pipa-pipa, dan masih digunakan hingga saat ini. Baik pemerintah Hindia-Belanda, hingga pemerintah saat ini dan masyarakat sekitar masih memanfaatkan mata air tersebut sebagai sumber pengairan. Sistem pengairan di wilayah Kebonarum-Gayamprit tidak hanya digunakan untuk keperluan perkebunan tembakau saja, namun justru lebih banyak digunakan untuk keperluan irigasi sawah pertanian. Sistem pengairan atau irigasi penting untuk kegiatan perkebunan tembakau. Sistem pengairan di sekitar lahan perkebunan dibuat dengan jalur-jalur tertentu dengan beberapa pipa beton pada setiap persimpangan jalur yang memiliki ketinggian yang berbeda, beberapa di antaranya, pada tepian jalurnya dilapisi dengan dinding semen. Sistem pengairan juga diperlukan di sekitar pabrik. Beberapa terlihat menggunakan pipa logam sebagai jalur air. 

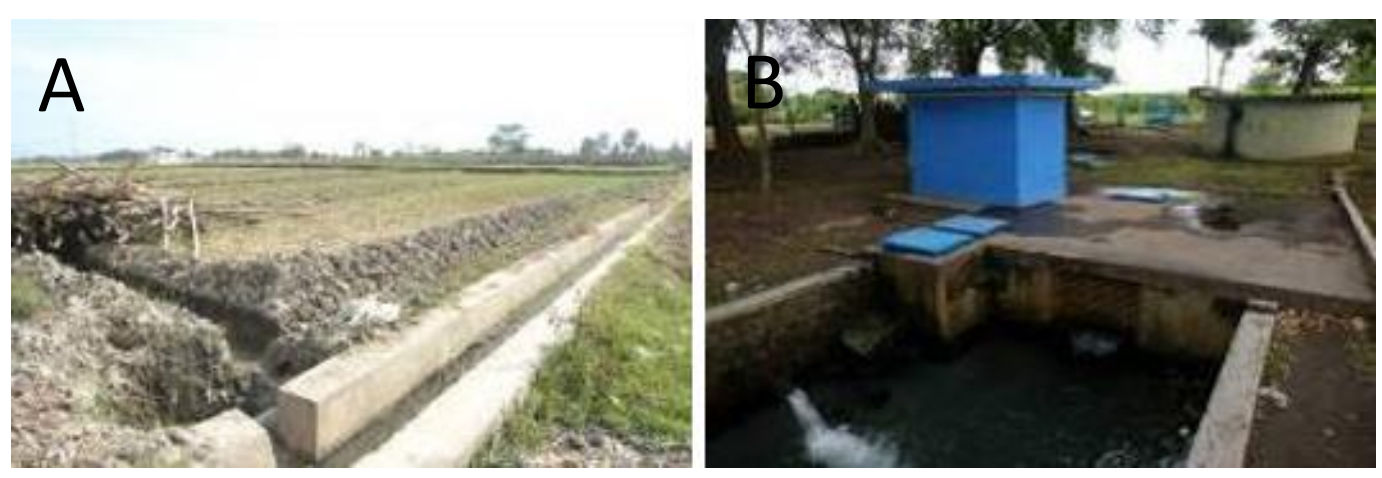

Gambar 8. (A) Jalur Irigasi di Sekitar Bangunan Los dan Perkebunan, (B) Mata Air Desa Geneng

(Sumber: Dokumentasi Penulis 2017)

\section{Pasar}

Apabila diamati, di setiap wilayah perkebunan terdapat pasar dengan skala kecil. Pasar di wilayah Kebonarum-Gayamprit terletak tidak jauh dari lokasi pabrik pengolahan. Lokasi pasar di sekitar perkebunan kebonarum adalah pasar Basin dan Pasar Kebonarum. Lokasi Pasar Basin terdapat di Barat pabrik, dan Pasar Kebonarum lebih jauh, terdapat di utara Pabrik Pengolahan Tembakau Kebonarum. Di Gayamprit, lokasi pasar terdapat di selatan Pabrik Pengolahan Tembakau Gayamprit.

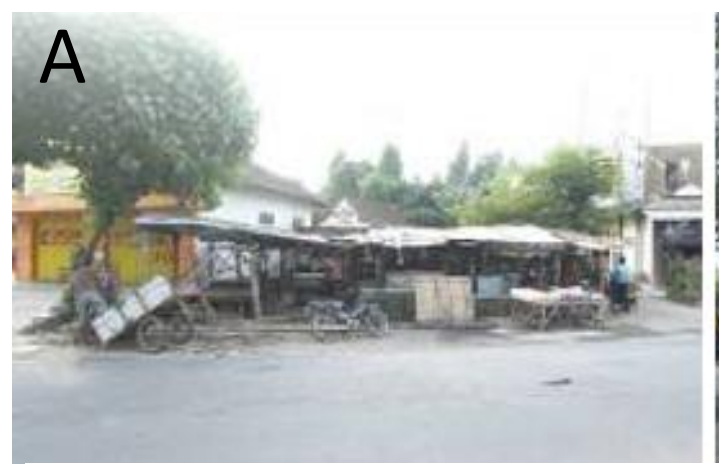

manusia dengan lingkungannya. Masing-masing tinggalan budaya, baik itu bangunan tunggal, lahan olahan seperti irigasi, sawah, dll., hingga situasi yang lebih kompleks seperti perkotaan, memiliki konteks dan hubungan antara satu komponen dengan komponen lainnya (Ashmore dan Knapp ed., 2000: 5-8).

Dari hal tersebut, komponenkomponen perkebunan wilayah Kebonarum-Gayamprit memiliki hubungan satu dengan lain dalam sebuah konteks budaya. Perkebunan merupakan kegiatan yang penting dalam menunjang perekonomian

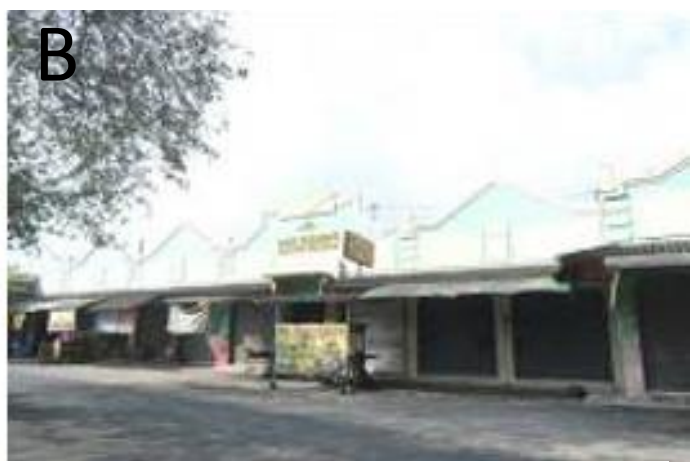

Gambar 9. (A) Kondisi Pasar Basin di Barat Pabrik Pengolahan Tembakau Kebonarum, (B) Kondisi Pasar Gayamprit di Selatan Pabrik Pengolahan Tembakau Gayamprit

(Sumber: Dokumentasi Penulis 2017)

\section{Hubungan Lanskap Komponen- Komponen Perkebunan}

Lanskap budaya dihasilkan oleh manusia, melalui kepercayaan, gagasan, dan perlakuan fisik, menjadikan adanya hubungan antara
Hindia-Belanda. Kegiatan perkebunan telah berdampak pada situasi sosial di Klaten berupa munculnya sistem perekonomian baru. Dampak sistem baru tersebut adalah masyarakat Klaten, pada 
Tabel 3. Pembentukan Desa Baru pada Area Perkebunan di Klaten Berdasarkan Vervolg Verslag Omnent den stand der Hervormingen in de Zelfbestuursgebieden Soerakarta en Mangkunegaran in het Gewest Soerakarta over het jaar 1919

\begin{tabular}{clc}
\hline No. & \multicolumn{1}{c}{ Wilayah } & Jumlah Desa \\
\hline 1. & Pandan Simping & 15 \\
2. & Gantiwarno & 13 \\
3. & Kemudho & 6 \\
4. & Wedi Birit & 12 \\
5. & Jiwo & 7 \\
\hline 6. & Demangan & 17 \\
\hline 7. & Ketandan & 13 \\
\hline 8. & Gayamprit & 10 \\
\hline & Total Desa Baru & 93 \\
\hline
\end{tabular}

Sumber: Padmo, 1999: 143

khususnya di wilayah KebonarumGayamprit memiliki mata pencaharian sebagai pekerja perkebunan tembakau, dengan sistem gaji yang berbeda dengan sistem upah dari kegiatan pertanian. Wilayah perkebunan tembakau di Kebonarum-Gayamprit terdapat di luar wilayah Kota Klaten. Wilayahnya termasuk ke dalam daerah pedesaan, meskipun dilihat dari peta, jarak antara wilayah perkebunan atau pedesaan Kebonarum-Gayamprit tidak begitu jauh dari Kota Klaten. Dalam lingkungan desa tentunya tidak akan dijumpai komponen-komponen perkotaan, yang berupa bangunanbangunan padat. Hal yang akan dijumpai adalah permukiman penduduk yang terpisah-pisah berdasarkan masing-masing wilayah desa. Komponen rumit yang terlihat adalah sistem persawahan atau perkebunan, dan jalur irigasi atau pengairan.

Wilayah perkebunan tembakau Kebonarum-Gayamprit, memiliki kegiatan produksi yang bernilai ekonomis, ini memunculkan adanya pusat "kota kecil" dalam wilayah desa. Hal ini terlihat dari adanya pasar di setiap wilayah perkebunan baik di Kebonarum maupun Gayamprit. Ditambah lagi dengan adanya rumah sakit, yang ditempatkan tidak jauh di antara kedua wilayah perkebunan. Hal tersebut memperlihatkan pada masa itu, masyarakat perkebunan telah memperhatikan kesehatan mereka.

Permukiman para pekerja terdapat di sekitar wilayah perkebunan. Para pekerja perkebunan merupakan penduduk setempat yang tinggal di wilayah KebonarumGayamprit. Sehingga perusahaan perkebunan tidak perlu menyediakan wilayah khusus, selain perumahan bagi para pegawai administrasi (administratuur). Hingga kini pun, sistem yang sama yakni pengambilan tenaga pekerja dari masyarakat sekitar, masih digunakan.

Kenampakan pada peta lama (lihat lampiran Gambar 10) dengan kenampakan saat ini mengenai komponen-komponen perkebunan tidak berbeda jauh. Meskipun saat ini telah terdapat penambahan permukiman, namun komponenkomponen perkebunan masih terlihat. Dari kenampakan peta saat ini (lihat lampiran Gambar 11-12), terlihat area perkebunan tetap ditempatkan di sekitar pabrik pengolahan tembakau. Kompleks pabrik baik di Kebonarum dan 
Gayamprit tidak mengalami perubahan, tetap pada wilayah tersebut, dan tidak mengalami perluasan. Wilayah perkebunan sangat bergantung pada dukungan sistem irigasi dan pembagian lahan dari sistem sewa. Dari peta lama, dapat terlihat ketersediaan lahan perkebunan yang luas pada masa itu mendukung produksi tembakau. Dari sistem irigasi yang baik, seperti yang terlihat dari peta lama tersebut (warna biru), adalah hal penting lain yang menjadi pokok dari kegiatan perkebunan. Ketersediaan air yang stabil, juga dapat menstabilkan produksi tembakau. Meskipun tidak terlihat pada peta saat ini, kondisi pengairan di kawasan KebonarumGayamprit tidak mengalami perubahan, dan kondisinya masih sangat baik. Keterangan pasar tidak dijelaskan pada peta lama, namun terdapat kenampakan berupa lambang bangunan semi permanen (persegi warna oranye) di selatan pabrik Gayamprit. Apabila di sesuaikan dengan kenampakan saat ini, letaknya masih sesuai.

Di samping kondisi aspek fisik yang terlihat pada daerah perkebunan, ada aspek sosial yang dapat ditelusur melalui segi historis. Sebelum dibukanya industri perkebunan di area KebonarumGayamprit, lahan di wilayah tersebut dikuasai oleh para patuh (sentana dan abdi dalem) yang diberikan tanah lungguh atau apanage. Tanah apanage adalah tanah milik kerajaan, pajak dari hasil penggunaan tanah tersebutlah (biasanya perkebunan dan pertanian) yang digunakan untuk menghidupi para patuh. Pejabat yang ditugaskan dalam mengawasi tanah tersebut disebut dengan bekel. la bertugas membawahi para petani yang ditugaskan untuk menggarap tanah tersebut. Gaji dari pengerjaan tanah berupa upah yang tergantung dari hasil panennya. Sistem organisasi semacam ini diperkirakan telah digunakan sejak masa Jawa Kuna (Suhartono, 1991: 27-30).

Pada era Hindia-Belanda, sistem apanage tersebut diubah. Melalui kerajaan, tanah-tanah apanage diambil alih kembali oleh Sultan atau Sunan yang memerintah, untuk kemudian disewakan kepada para pengusaha perkebunan. Para patuh tidak memperoleh pajak dari hasil tanah melainkan dari uang hasil sewa tanah perkebunan, yang telah ditentukan dari kerajaan. Di tingkat pedesaan, dibentuklah sistem organisasi baru yaitu perangkat desa, yang diangkat berdasarkan proses pemilihan, meliputi lurah, demang, dan ronggo. Mulai dari lurah, bekel, hingga kuli yang menjadi pekerja perkebunan, diberikan upah berupa gaji uang yang telah ditentukan pihak perusahaan perkebunan (Padmo, 1999: 132-134; 138-140; Suhartono, 1991: 94-99).

Hal tersebut telah membentuk hubungan sosial yang baru. Rakyat yang pada awalnya berada di bawah para penguasa kerajaan, berganti menjadi rakyat sebagai pekerja, yang berada di bawah pemberi kerja profesional, dalam hal ini perusahaan perkebunan, yang memberikan gaji berupa uang. Masyarakat di pedesaan tidak lagi kesulitan dalam proses penukaran barang produksi panen untuk konsumsi mereka, karena uang merupakan alat tukar yang praktis. Masyarakat tidak perlu lagi menukarkan hasil panen mereka ke pusat perekonomian di kota, melainkan mendatangkan produsen yang menjual kebutuhan masyarakat ke pedesaan. Sistem konsumtif seperti itu menimbulkan adanya proses ekonomi yang cepat di pedesaan, memunculkan sarana perekonomian strategis antara lain berupa pasar di lingkungan desa. 
Adanya sistem pemilihan menimbulkan demokrasi pada lingkungan pedesaan. Rakyat tidak lagi serta merta tunduk secara langsung kepada kerajaan, namun dapat memberikan suara terhadap siapa yang memimpinnya. Dengan budaya seperti itu, wibawa yang dulu melekat pada para penguasa dari kerajaan mulai menghilang, digantikan dengan politik desa, di mana kekuasaan berada ditangan pemberi gaji. Dengan adanya demokrasi, rakyat sebagai pekerja juga tidak begitu saja tunduk kepada atasan, namun juga berhak melakukan protes untuk menuntut hak-hak mereka sebagai pekerja.

Sistem organisasi yang baru tersebut merupakan sistem modern yang telah berkembang di negara barat. Industri perkebunan di lingkungan pedesaan telah memunculkan modernisasi di lingkungan desa. Kepentingan sosial yang menjadi faktor utama industrialisasi telah memberikan dampak berupa perubahan fisik di lingkungan pedesaan.

\section{KESIMPULAN}

Wilayah perkebunan
merupakan wilayah di luar lingkungan kota yang memiliki sistem sosial sendiri. Lingkungannya berada di daerah pedesaan sehingga komponen-komponennya tidak sekompleks komponen perkotaan. Wilayah perkebunan KebonarumGayamprit masih dapat memperlihatkan perkembangan wilayah pedesaan sebagai wilayah yang mandiri dari Kota Klaten pada masa pemerintahan Hindia-Belanda. Salah satunya adalah memiliki pasar sebagai pusat perekonomian masyarakat di sekitarnya. Hal tersebut dapat memperlihatkan bagaimana masyarakat di pedesaan tidak bergantung pada perekonomian kota saja.

Industri perkebunan menimbulkan budaya baru pada masyarakat pedesaan Klaten masa itu. Sejak adanya industri tembakau, dibuka beberapa wilayah desa sebagai permukiman dan area perkebunan baru di Klaten. Sistem re-organisasi, juga merupakan salah satu pemicu terbesar adanya modernitas yang menghilangkan budaya kultus kerajaan dalam masyarakat Jawa. Kemudian banyak masyarakat pedesaan dapat berkembang mengikuti budaya masyarakat kota dan masyarakat modern Eropa.

Hubungan antara Kota Klaten dengan wilayah perkebunan di daerah pedesaan Klaten tetap tidak dapat dipisahkan. Kota Klaten tumbuh akibat salah satunya produksi perkebunan yang maju pada awal abad XX. Banyaknya pengusaha asing yang menanamkan investasi di Klaten menyebabkan berkembangnya komponen kota sebagai fasilitas pendukung masyarakat Eropa yang modern.

Lanskap wilayah per-kebunan Kebonarum-Gayamprit yang sedemikian rupa, memperlihatkan kompleksitas dan keragaman masyarakat yang hidup di pedesaan, tidak hanya dari masyarakat pribumi namun juga warga asing yang dulu tinggal di daerah tersebut.

\section{UCAPAN TERIMA KASIH}

Penulis mengucapkan terima kasih kepada Departemen Arkeologi UGM, para pekerja perkebunan, dan warga Kebonarum dan Gayamprit, serta pihak-pihak lain yang telah membantu penulis dalam penyelesaian karya tulis ini. 


\section{DAFTAR PUSTAKA}

Anschuetz, Kurt F., dkk. 2001. "An Archaeology of Landscapes: Perspectives and Directions" dalam Journal of Archaeological Research, Vol. 9, No. $2 \mathrm{hlm}$. 157-211. New York: Plenum Publishing Corporation.

Ashmore, Wendy dan A. Bernard Knapp. 2000. Archaeologies of Landscape. Oxford: Blackwell.

Dell, Melissa dan Benjamin A. Olken. 2017. "The Development Effects of the Extractive Colonial Economy: The Dutch Cultivation System in Java", Artikel. Harvard University dan MIT.

Djajadi, Djajadi. 2015. "TOBACCO DIVERSITY IN INDONESIA A REVIEW" dalam Journal of Biological Researches: 20 hal 27-32.

Nagari, Galih Sekar Jati. "Tata Kota Klaten Tahun 1923-1930 Berdasarkan Peta Topografi 1933 Dan 1935". Skripsi. Yogyakarta: FIB UGM.

Padmo, Sugijanto. 1999. Tobacco Plantations and Their Impact on Peasant Society and Economy in Surakarta Residency: 1860-1980s. Yogyakarta: Aditya Media.

Padmo, Sugijanto. 2007. "Sejarah Kota dan Ekonomi Perkebunan" dalam Makalah Diskusi Sejarah Balai Pelestarian Sejarah dan Nilai Tradisional. Yogyakarta Departemen Kebudayaan dan Pariwisata.

PPEB FEB UNS. 2007. "Evolusi Ekonomi Kota Solo". Laporan Penelitian. Surakarta: FE UNS.

Saraswati, Titien. 2008. "Vernakularitas Los, Bangunan Pengering Tembakau Di Kabupaten Klaten, Jawa Tengah" dalam Dimensi Teknik Arsitektur Vol. 36 No. 1. Surabaya: Universitas Kristen Petra.

Suhartono, Dr. 1991. Apanage dan Bekel. Yogyakarta: PT. Tiara Wacana.

Sujatmiko, Bagus Tri. 2014. "Tata Ruang Kompleks Pabrik Pengolahan Tembakau Kebonarum Klaten, Jawa Tengah”. Skripsi. Yogyakarta: FIB UGM.

Tim Penyusun Hari Jadi Kab. Klaten. 2005. Studi Penelitian Hari Jadi Kabupaten Klaten. Klaten: Kantor Pariwisata Kab. Klaten bekerja sama dengan LPPM UNS Surakarta.

Zadoks, Jan C. (ed.). 2014. Black Shank of Tobacco in the Former Dutch East Indies, Caused by Phythophthora Nicotianae. Leiden: Sidestone Press.

Sumber Lain: 
Pusat Penelitian Tembakau PTPN X (Persero) Klaten. 2012. "Sejarah Penelitian Tembakau Klaten", https://puslitklaten.wordpress.com/about/. Diakses pada 30 Mei 2017.

Topografischen dienst Batavia. 1935. "KLATEN Herzien door den Topografischen dienst”, http:// media-kitlv.nl. Diakses pada 02 Juni 2017. 


\section{Lampiran}

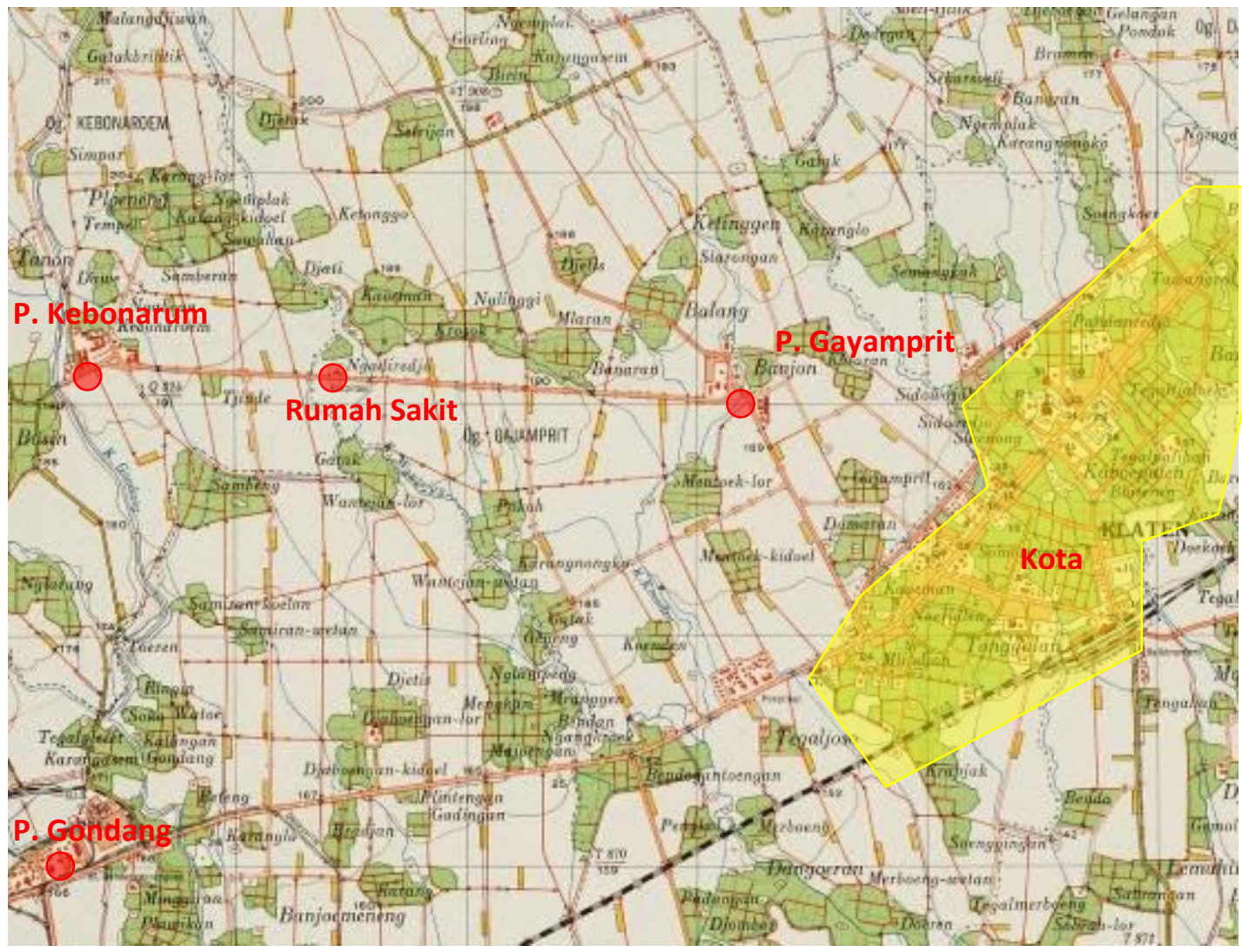

Gambar 9. Keletakan Perkebunan Tembakau Kebonarum-Gayamprit dalam Peta 1933

(Sumber: Sumber: media-kitlv.nl dengan modifikasi penulis)

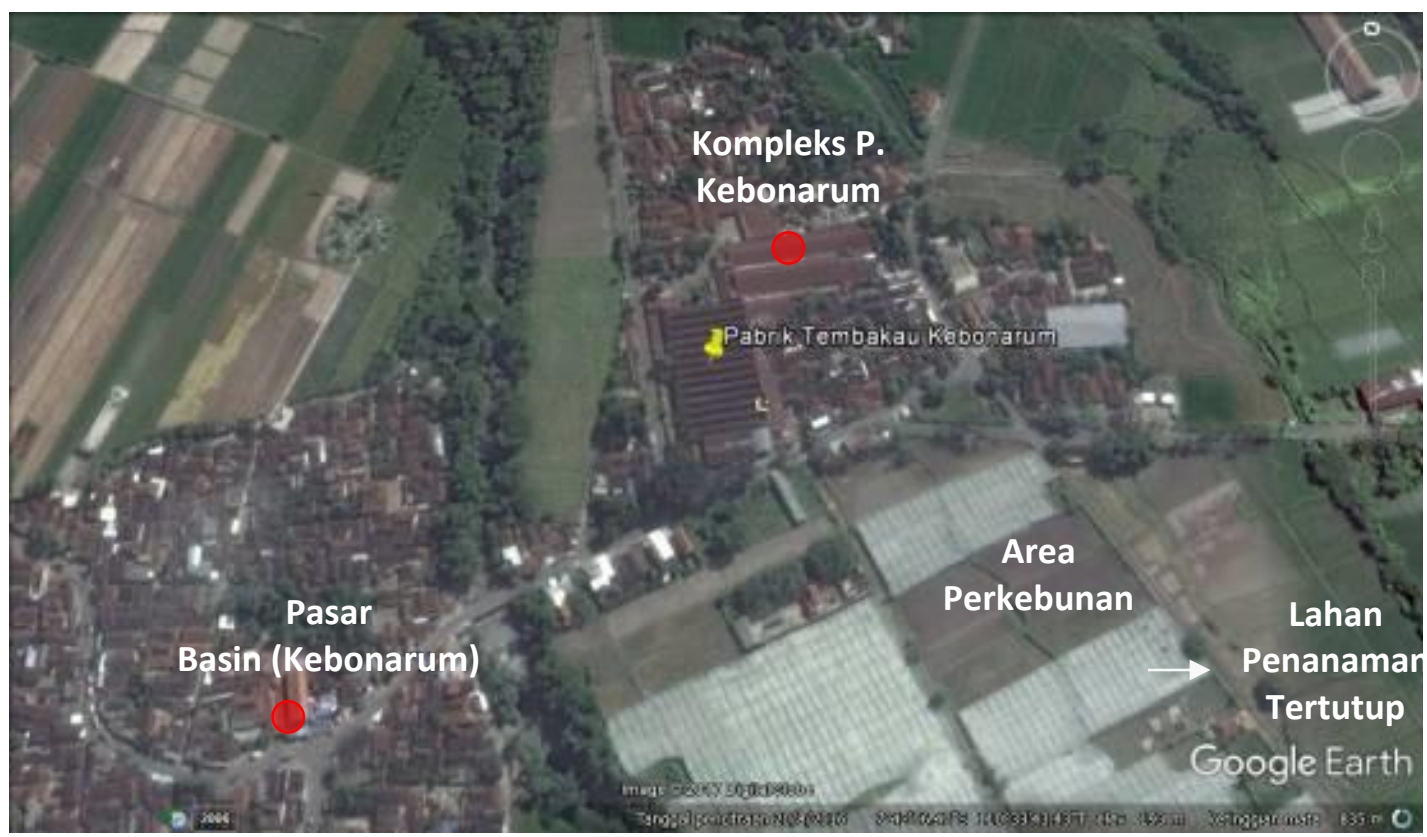

Gambar 10. Keletakan Wilayah Perkebunan Kebonarum Saat Ini

(Sumber: Google Earth dengan modifikasi penulis)

Lanskap Perkebunan Tembakau Kebonarum dan Gayamprit Kabupaten Klaten 


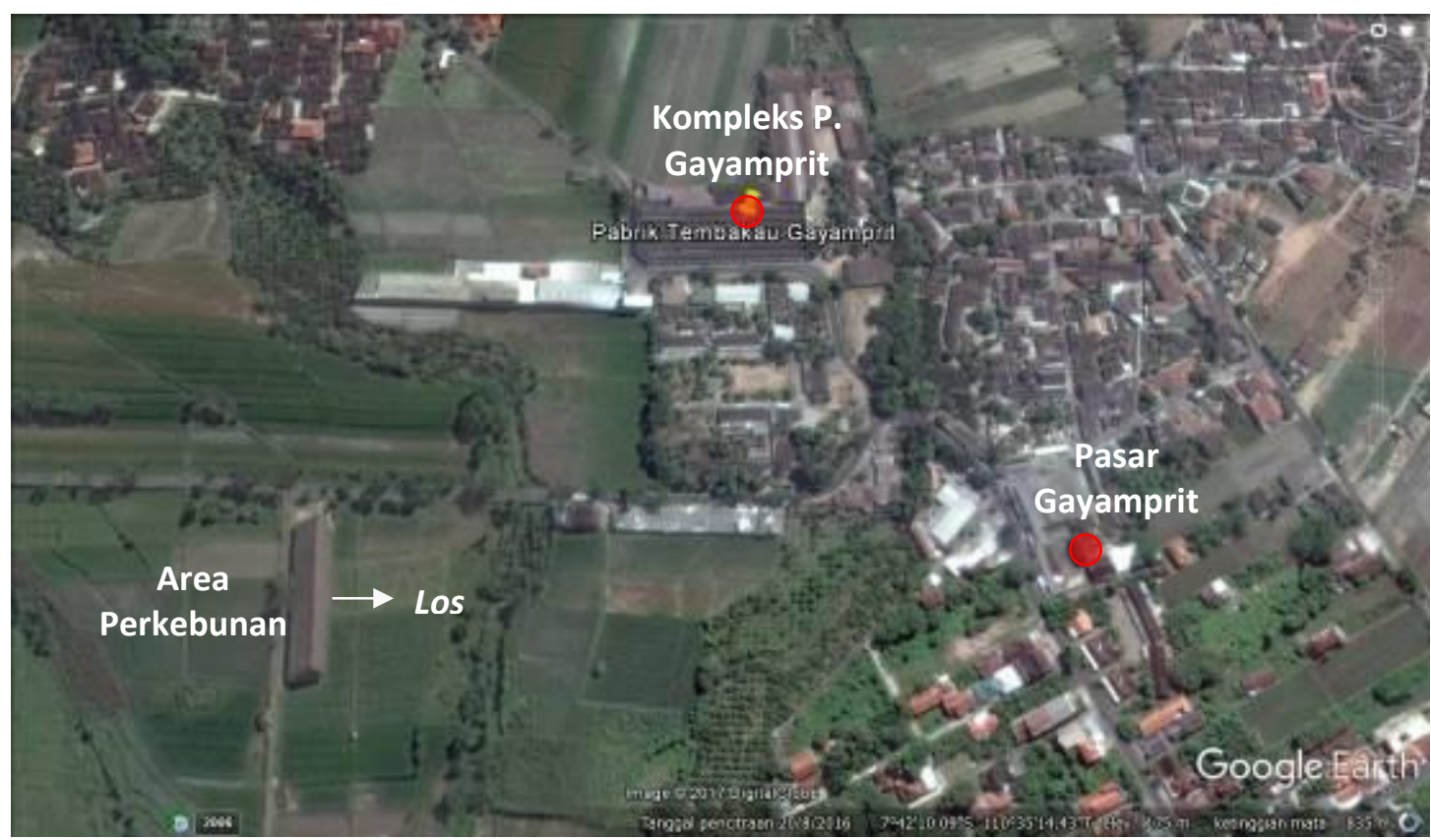

Gambar 11. Keletakan Wilayah Perkebunan Gayamprit Saat Ini (Sumber: Google Earth dengan modifikasi penulis) 